\title{
Effect of Exogenous Potassium on the Reduction in Tar, Nicotine and Carbon Monoxide Deliveries in the Mainstream Smoke of Cigarettes*
}

\author{
by T. Yamamoto, S. Umemura and H. Kaneko \\ Central Research Institute, Japan Tobacco Inc., Yokobama, Japan
}

\section{SUMMARY}

Deliveries of tar, nicotine and carbon monoxide in mainstream smoke decreased as the exogenous-potassium content of tobacco increased. The puff count was almost unchanged with added potassium malate, but slightly decreased with added nitrate. Potassium malate was more effective than the nitrate for the reduction of carbon monoxide, whereas the opposite was observed in the case of nicotine. Both the exogenous and the endogenous potassium contents influenced the reduction of carbon-monoxide delivery through a decrease in the peak temperature of the burning cone. The pungency and off-taste peculiar to the tobacco were eliminated to some extent by the addition of potassium malate at levels less than $2 \%$ expressed as potassium.

\section{ZUSAMMENFASSUNG}

Der Gehalt des Hauptstromrauches an Kondensat, Nicotin und Kohlenmonoxid verminderte sich mit zunehmendem dem Tabak von außen zugeführtem Kalium. Die Zugzahl veränderte sich durch zugesetztes Kaliummalat kaum, ging jedoch bei zugesetztem Kaliumnitrat geringfūgig zurūck. Der Kohlenmonoxidgehalt wurde durch den Einfluß von Kaliummalat stärker vermindert

\footnotetext{
* Received: 28th April 1987 - accepted: 6th May 1988.
}

als durch Kaliumnitrat, wohingegen sich das Nicotin umgekehrt mehr durch Kaliumnitrat als durch Kaliummalat verringerte. Die Verminderung der Kohlenmonoxidausbeute durch exogenes wie auch endogenes $\mathrm{Kali}$ um erfolgt über das Absenken der Maximaltemperatur im Glutkegel. Das Zusetzen von Kaliummalat (gemessen als Kalium) in Mengen von unter $2 \%$ führte bis zu einem gewissen Grad zu einer Abmilderung des dem Tabakrauch eigenen beißenden Geruchs und unangenehmen Geschmacks.

\section{RESUME}

Ces travaux ont montré que la teneur en condensat, en nicotine et en monoxyde de carbone de la fumée du courant principal diminuait quand la quantité de potassium exogène contenue dans le tabac augmentait. Le nombre de bouffées ne s'est pratiquement pas trouvé modifié par l'addition de malate de potassium, mais il a par contre été légèrement plus faible à la suite de l'addition de nitrate de potassium. La teneur en monoxyde de carbone a plus fortement diminué dans le cas du malate que dans celui du nitrate de potassium, alors que le contraire a été observé en ce qui concerne la nicotine. La moindre production de monoxyde de carbone sous l'effet du potassium tant exogène qu'endogène est imputable à l'abaissement de la température maximale dans le cône de combustion. L'addition de malate de potassium à raison de quantités inférieures à $2 \%$ de 
Table 1. Cigarette samples.

\begin{tabular}{|c|c|c|c|c|c|c|}
\hline \multirow[b]{2}{*}{ Salts } & \multicolumn{3}{|c|}{ Cutter } & \multicolumn{3}{|c|}{ Leaf } \\
\hline & $\begin{array}{c}\text { Potassium } \\
\text { added * } \\
(\%)\end{array}$ & $\begin{array}{c}\text { Woight } \\
\text { (g) }\end{array}$ & $\begin{array}{c}\text { Pressure } \\
\text { drop } \\
\text { (mm. w.g.) }\end{array}$ & $\begin{array}{l}\text { Potassium } \\
\text { added * } \\
(\%)\end{array}$ & $\begin{array}{c}\text { Weight } \\
\text { (g) }\end{array}$ & $\begin{array}{l}\text { Pressure } \\
\text { drop } \\
\text { (mm w.g.) }\end{array}$ \\
\hline None & 0 & $1.05+0.01$ & $62+2$ & 0 & $1.07+0.01$ & $52+2$ \\
\hline Malate & 0.49 & $1.05+0.01$ & $61+2$ & 0.36 & $1.07+0.01$ & $50+2$ \\
\hline Nitrate & 0.48 & $1.05+0.01$ & $61+2$ & 0.48 & $1.07+0.01$ & $50+2$ \\
\hline Malate & 0.91 & $1.05+0.01$ & $60+2$ & 0.89 & $1.07+0.01$ & $48+2$ \\
\hline Nitrate & 0.90 & $1.05+0.01$ & $60+2$ & 0.91 & $1.07+0.01$ & $48+2$ \\
\hline Malate & 1.19 & $1.05+0.01$ & $58+2$ & 1.22 & $1.07+0.01$ & $46+2$ \\
\hline Nitrate & 1.35 & $1.05+0.01$ & $58+2$ & 1.10 & $1.07+0.01$ & $46+2$ \\
\hline Malate & 1.59 & $1.05+0.01$ & $56+2$ & 1.69 & $1.07+0.01$ & $44+2$ \\
\hline Nitrate & 1.46 & $1.05+0.01$ & $56+2$ & 1.78 & $1.07+0.01$ & $44+2$ \\
\hline Citrate & 1.80 & $1.05+0.01$ & $56+2$ & & & - \\
\hline Acetate & 1.83 & $1.05+0.01$ & $56+2$ & & & \\
\hline Oxalate & 1.74 & $1.05+0.01$ & $56+2$ & & & \\
\hline
\end{tabular}

Fractional volume: $0.305-0.317$.

- Percentage values on the basis of the aclual tobacco weight.

potassium a entraîné dans une certaine mesure un adoucissement de l'odeur âcre et du goût désagréable propres à la fumée de tabac.

\section{INTRODUCTION}

In previous studies (1), it was found that the level of carbon monoxide [CO] in mainstream smoke decreased, believed to be due to the lowering of the burning temperature during puffs, with increase in the potassium content of tobacco. Endogenous potassium in tobacco leaf is related to other chemical constituents and physical properties of the leaf which are also important when tobacco burns. To clarify further the role of potassium in the reduction of $\mathrm{CO}$, it is necessary to investigate the effect of exogenous potassium added to tobacco material.

A number of investigations have been reported on the effect of exogenous potassium and/or sodium on the burn rate $(2-5)$ and smoke components $(6-10)$ of tobacco. However, there has been no report on the effect of these exogenous alkali-metal ions on the formation of $\mathrm{CO}$ because of their effect on the burning tem-. perature of tobacco.

The present paper describes the effect of exogenous potassium not only on $\mathrm{CO}$ but also on tar and nicotine in the mainstream smoke and its relationship to changes in the burning temperature. The use of potassium malate as a tobacco additive for reducing these smoke components and improving the aroma and taste of tobacco smoke is discussed.

\section{EXPERIMENTAL}

Cutter and leaf laminae of bright tobacco (cv. MC), the same as used in the previous experiments (1), were cut to a width of $0.8 \mathrm{~mm}$. Aqueous solutions of potassium salts $(30 \mathrm{ml})$ were sprayed on $200 \mathrm{~g}$ samples of the cut tobacco. The shredded control sample was sprayed with $30 \mathrm{ml}$ of water. The samples were then dried for about $20 \mathrm{~min}$ at $45^{\circ} \mathrm{C}$. Sample cigarettes were made from these shreds with ordinary cigarette paper (permeability: about $10 \mathrm{ml} / \mathrm{cm}^{2} / \mathrm{min} / 100 \mathrm{~mm}$ w.g.) and a length and circumference of $70 \mathrm{~mm}$ and $25 \mathrm{~mm}$, respectively. After conditioning at $22^{\circ} \mathrm{C}$ and $60 \%$ relative humidity for several days, the cigarettes were weight and pressure-drop selected (Table 1). With a constant packing density per cigarette, the mean value of the pressure drop decreased as the amount of potassium salt increased. This seems to be due to some decrease in the fractional volume of the tobacco because the apparent density of the shreds increased slightly with the increase in the amount of the additive. As shown in Table 1, however, the difference between the fractional volume of sample and control-cigarette tobaccos was small. The amounts of exogenous potassium shown in Table 1 were lower than the values expected $(0.5 \%$, $1.0 \%, 1.5 \%$ and $2.0 \%$ ). These data indicate the efficiency of salt addition by this procedure to be in the range from $72 \%$ to $98 \%$. The methods used for determining tar, nicotine, $\mathrm{CO}$, and potassium were the same as described previously (1). Temperature measurements were made with a thermocouple, as reported previously. Sensory tests were carried out by an expert panel in our Institute. They scored the evaluation for the 
pungency and off-taste of smoke peculiar to the tobacco.

\section{RESULTS AND DISCUSSION}

\section{Effect of Potassium Malate and Nitrate on the Puff Count}

Figure 1 shows the effect of exogenous potassium on the puff count, an index of tobacco combustibility. The puff count decreased slightly as the potassium nitrate increased. On the other hand, it remained almost constant with added potassium malate. Potassium and sodium nitrates are both known to accelerate tobacco combustion. In this case, the predominant role for combustion is played by these alkali metals (2), whereas the promoting effect of nitrate anion is considered to be attributable to the oxygen evolved by thermal decomposition of the nitrate. The effect of the nitrate on the reduction in puff count in the present experiment is consistent with past observations $(2,3,6,9)$.

\section{Figure 1.}

Effect of exogenous potassium on the puff count.

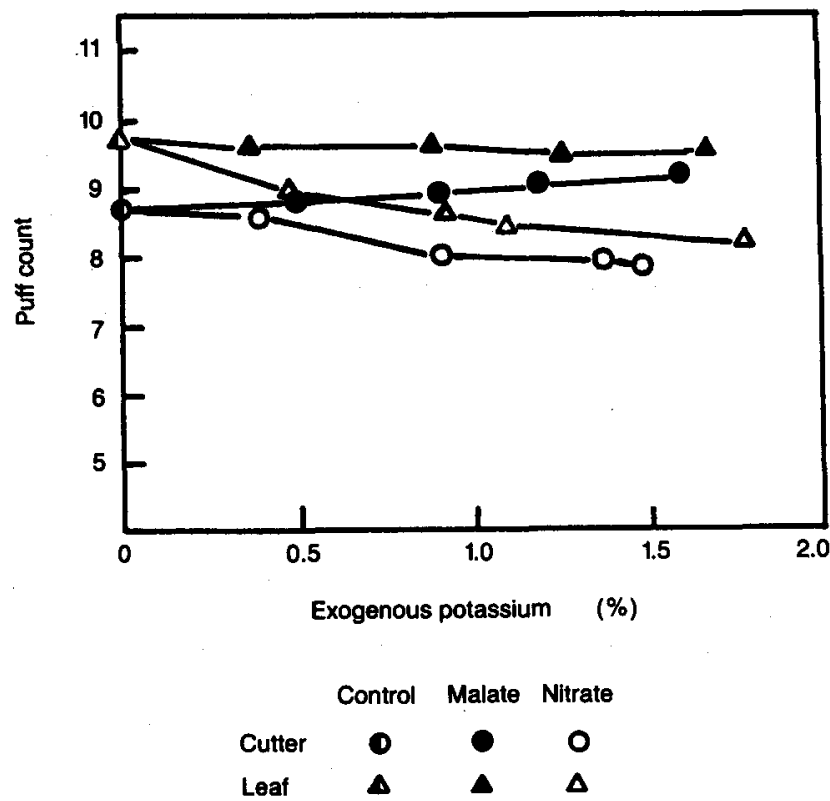

Effect of Potassium Malate and Nitrate on the Reduction in Smoke Components

The reductions in smoke-component levels are shown in Figures 2 to 4, which indicate the percentage reduction in the amount of each component with addition of potassium. These figures show that tar, nicotine and
CO are reduced by about $20 \%$ by adding $1 \%$ to $1.5 \%$ (w/w) of potassium based on tobacco shred weight. As shown in Figure 2, the reduction in tar is mainly dependent on the amount of exogenous potassium and almost independent of the salt type or the leaf/stalk position. In general, tar is formed by thermal decomposition of tobacco at temperatures below about $450^{\circ} \mathrm{C}$. According to thermal-analysis experiments $(6,11$ to 13$)$, the initial and the most active temperatures of thermal decomposition of organic substances with potassium salts are lower than those without salts. The weight loss by thermal decomposition is also somewhat small, resulting in a larger amount of carbon residue. Perhaps, potassium plays such a role in the thermal decomposition of tobacco and this is the reason for the reduction in tar delivery which appears to be dependent on the amount of exogenous potassium, but independent of the kind of salts and the stalk position of the tobacco leaf (Figure 2).

Nitrate was more effective than malate in reducing nicotine delivery (Figure 3) while the reverse was observed in $\mathrm{CO}$ reduction (Figure 4).

\section{Peak Temperature and Smoke Components}

Figure 5 shows the effect of exogenous potassium on the peak temperature of the burning cone during a puff. The temperature decreased with increase in the potassium added as either malate or nitrate. The difference of peak temperature, observed with the two salts, appeared at about $1 \%$ potassium addition; the malate was more effective than the nitrate in decreasing the peak temperature.

The effect of peak temperature on $\mathrm{CO}$ delivery is shown in Figure 6. With increasing peak temperature, the $\mathrm{CO}$ delivery increased almost linearly, being independent of the kind of the salts or the leaf/stalk position. It is well known that $\mathrm{CO}$ is formed by thermal decomposition of tobacco, combustion of carbon residue, and carbonaceous reduction of $\mathrm{CO}_{2}(14-16)$. The last reaction, an endothermic one, is promoted by a higher temperature. This is thought to be the reason for the temperature dependence of CO delivery (Figure 6). In addition, the fact that malate is more effective than nitrate in reducing $\mathrm{CO}$ delivery (Figure 4) can be explained by the greater influence of malate than nitrate on the decrease in the peak temperature (Figure 5). Thus, both exogenous and endogenous potassium are effective in reducing the delivery of $\mathrm{CO}$ by decreasing the peak temperature.

As shown in Figure 7, the delivery of nicotine was relatively low with the nitrate at the same temperature. The nicotine is delivered from tobacco to smoke by volatilization during combustion, and a considerable amount of it is thermally degraded. Nicotine degradation is greater in the presence of oxygen than in the presence of an inert gas $(17,18)$. The interior region of the burning cone, where the thermal decomposition of 
Figure 2.

Effect of exogenous potasslum on the tar reduction rate.

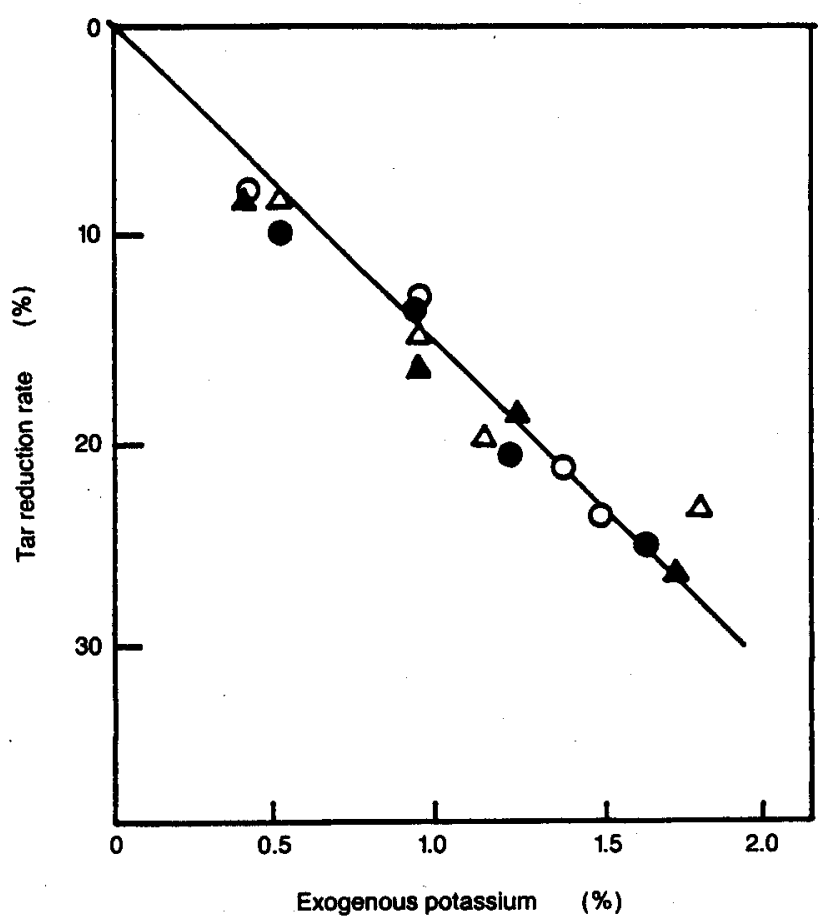

Figure 3.

Effect of exogenous potassium on the nicotine reduction rate.

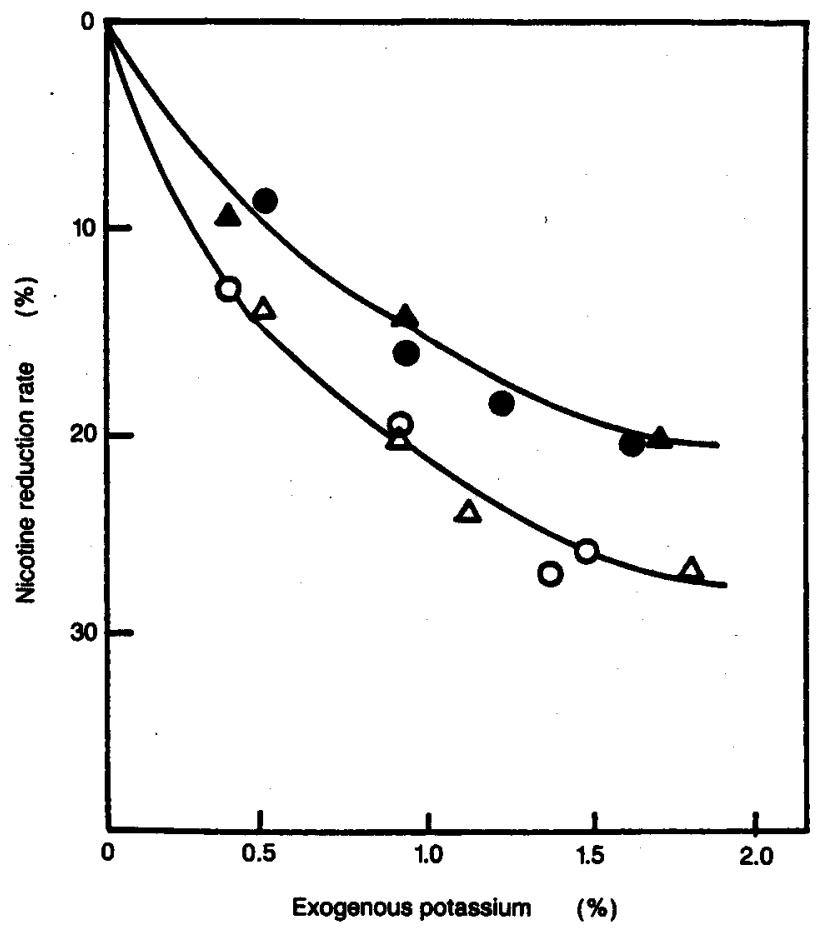

Figure 4.

Effect of exogenous potassium on the carbon-monoxide reduction rate.
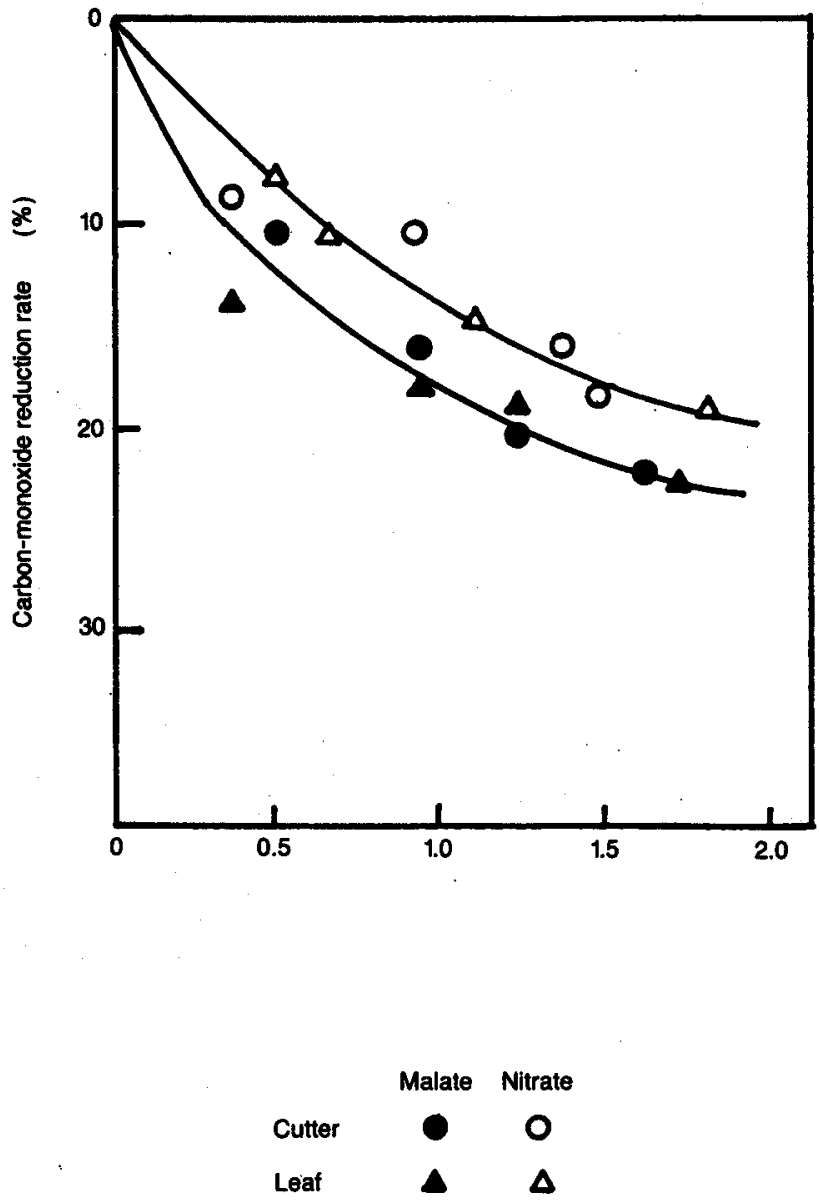
Flgure 5.

Effect of exogenous potasslum on the peak temperature.

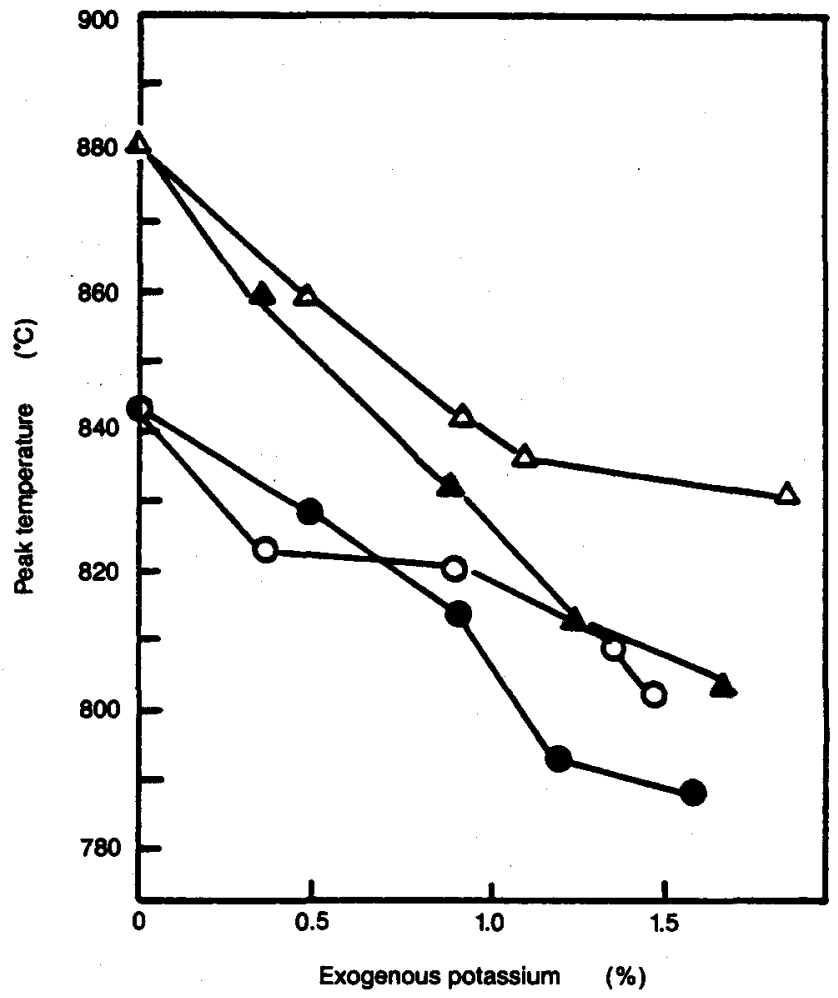

Figure 6.

Relationship between peak temperature and carbon-monoxide dellvery.

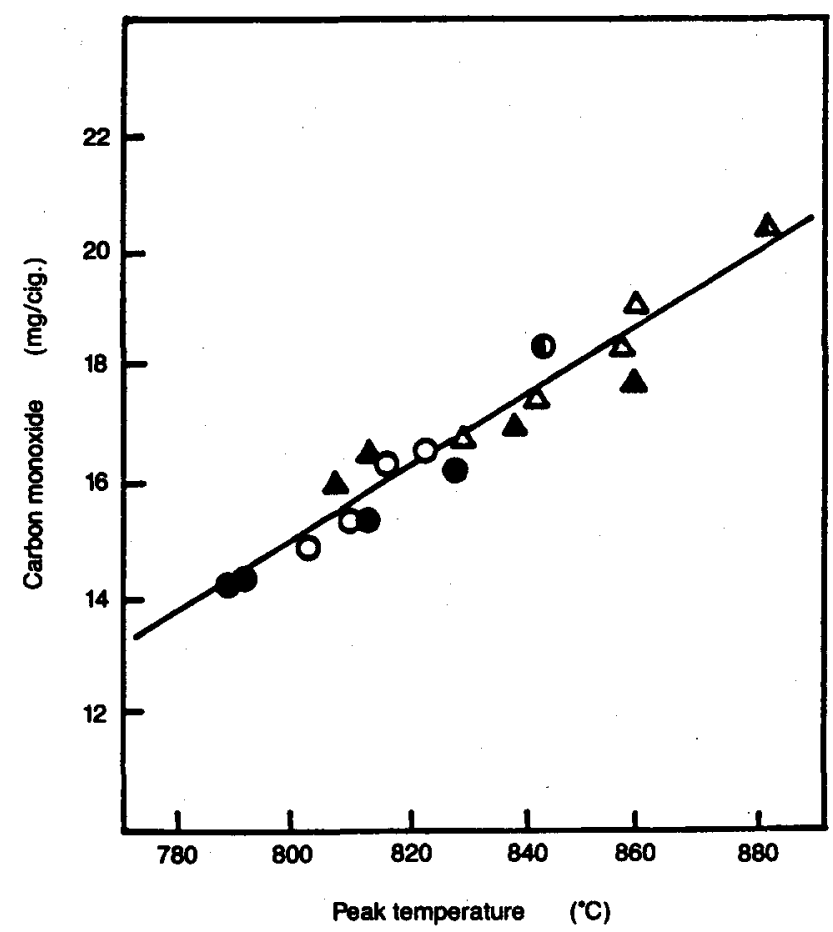

Figure 7.

Relationshlp between peak temperature and nicotine deIlvery.

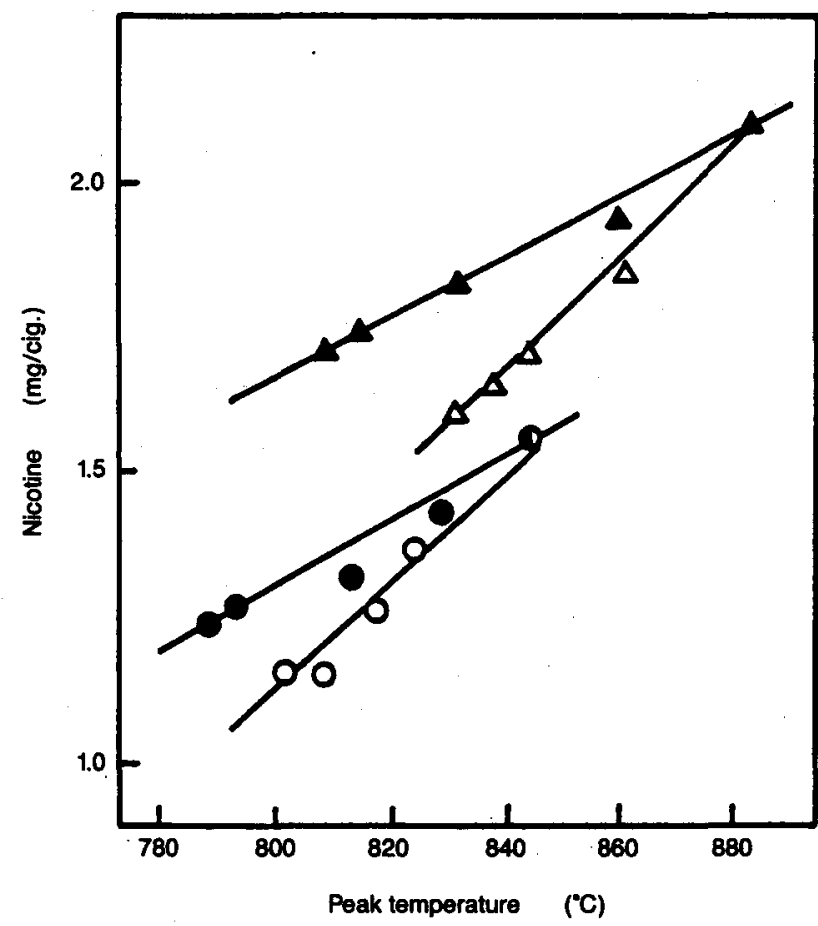

$$
\begin{array}{lccc} 
& \text { Control } & \text { Malate } & \text { Nitrate } \\
\text { Cutter } & 0 & 0 & 0 \\
\text { Leaf } & \Delta & \Delta & \Delta
\end{array}
$$


tobacco occurs, is oxygen deficient during a puff because of the oxygen consumption during combustion $(14,19,20)$. Since the amount of endogenous nitrate in bright tobacco lamina is very small $(21-23)$, the exogenous nitrate is thought to contribute to an increase in oxygen concentration during its thermal decomposition $(24,25)$. Thus, it is reasonable to suggest that nitrate is more effective than malate in the reduction of nicotine delivery (Figures 3 and 7).

\section{Effect of Organic Potassium Salts}

The effects of several potassium salts of organic acids on the reduction in the tar, nicotine and $\mathrm{CO}$ deliveries are shown in Table 2. With the addition of any of these salts, decreases in the deliveries of these smoke components were observed.

Overall, malate was slightly more effective than other organic salts in reducing nicotine and $\mathrm{CO}$ deliveries. Little difference in the puff count was observed with these salts. Sensory tests were carried out by an expert panel on the cigarettes treated with the malate, citrate and acetate. Their comments were as follows: pungency and off-taste peculiar to the tobacco were elimi-

\section{REFERENCES}

1. Yamamoto, T., Y. Suga, X. Kaneki and H. Kaneko: Effect of chemical constituents on the formation rate of carbon monoxide in bright tobacco (presented at the CORBSTA Symposium held in Taormina, Italy, in 1986); CORESTA Information Bulletin 1986, Special Issue, p. 102 as well as Beitr. Tabakforsch. Int. 14 (1989) 163-170.

2. Yamamoto, T., and $H$. Tomita: Effect of organic and inorganic salts on the static burning rate of cellulose model cigarettes; Jpn. Tob. Salt Public Corp. Cent. Res. Inst. Sci, Pap. 120 (1978) 93-97.

3. Resnik, F. E., W. G. Houck, W. A. Geiszler and J. E. Wickham: Factors affecting static burning rate; Tob. Sci. 21 (1977) 103-107.

4. Aksu, S.: Einige organische Salze als Feuchthaltemittel in Cigaretten; Beitr. Tabakforsch. 5 (1969) 18-19.

5. Pyriki, C., and W. Philipp: Der Einfluß verschiedener anorganischer Salze auf die Glimmfähigkeit des fermentierten Tabaks; Ber. Inst. Tabakforsch. Dresden 2 (1955) 94-111.

6. Burdick, D., J. F. Benner and H. R. Burton: Thermal decomposition of tobacco, IV. Apparent correlations between thermogravimetric data and certain constituents in smoke from chemically treated tobaccos; Tob. Sci. 13 (1969) 138-141.

7. Mattina, C. F., and W. A. Selke (Kimberly-Clark Corp.): Tobacco composition for smoking; Patent FR 2,527,055 [Chem. Abstr. 100 (1984) No. $83004 \mathrm{~m}$ ].
Table 2.

Effect of organic potasslum salts on smoke-component deliverles.

\begin{tabular}{|c|c|c|c|c|c|}
\hline \multirow[b]{2}{*}{ Salts } & \multirow{2}{*}{$\begin{array}{c}K \\
\text { added } \\
(\%)\end{array}$} & \multirow{2}{*}{$\begin{array}{l}\text { Puff } \\
\text { count }\end{array}$} & \multicolumn{3}{|c|}{ Smoke components (mg/cig.) } \\
\hline & & & tar & $\begin{array}{l}\text { nic- } \\
\text { otine }\end{array}$ & $\mathrm{CO}$ \\
\hline None & 0 & 8.7 & 26.8 & 1.56 & 17.8 \\
\hline Malate & 1.59 & 9.1 & 20.0 & 1.24 & 14.2 \\
\hline Cltrate & 1.80 & 8.8 & 19.4 & 1.27 & 14.3 \\
\hline Acetate & 1.83 & 8.4 & 19.5 & .1 .34 & 15.0 \\
\hline Oxalate & 1.74 & 8.7 & 20.8 & 1.41 & 16.3 \\
\hline
\end{tabular}

nated to some extent by the addition of potassium malate as compared with the control cigarette. Moreover, malate reduced pungency and off-taste more effectively than the other two organic salts. These results suggest that potassium malate may not only be effective as tobacco additive for the reduction of tar, nicotine and $\mathrm{CO}$ deliveries but also for the improvement of aroma and taste of tobacco smoke.

8. Terrell, J. H, and I. Schmeltz: Alteration of cigarette smoke composition, I. Influence of certain additives; Tob. Sci. 14 (1970) 78-81.

9. Muramatsu, M., Y. Shimada and H. Tomita: Effect of some additives on the combustion process and smoke composition of cigarette; Jpn. Tob. Salt Public Corp. Cent. Res. Inst. Sci. Pap. 116 (1974) 65-69.

10. Rathkamp, G., and D. Hoffmann: Chemical studies on tobacco smoke, XIII. Inhibition of the pyrosyntheses of several selective smoke constituents; Beitr. Tabakforsch. 5 (1970) 302-306.

11. Sasaki, N., H. Araki, M. Suzuki and T. Nagasawa: Pyrolysis of lignins and related compounds, III. Determination of low molecular-weight compounds in pyrolysis products; Mokuzai Gakkaishi 32 (1986) 358-365.

12. Yamazaki, A., K. Takeda, A. Mikita and K. Maeda: Thermal decomposition of cigarette paper, II. Pyrolysis of cigarette paper from flax pulp blended with wood pulp treated with various burning chemicals; Japan Tappi 39 (1985) 1063-1072.

13. Umemura, S.: Unpublished data.

14. Baker, R. R.: Mechanisms of smoke formation and delivery; Recent Adv. Tob. Sci. 6 (1980) 184-224.

15. Baker, R. R.: Formation of carbon oxides during tobacco combustion - Pyrolysis studies in the presence of isotopic gases to elucidate reaction sequence; J. Anal. Appl. Pyrolysis 4 (1983) 297-334. 
16. Baker, R. R.: The effect of ventilation on cigarette combustion mechanisms; Recent Adv. Tob. Sci. 10 (1984) 88-150.

17. Kobashi, Y., H. Hoshaku and M. Watanabe: Thermal degradation of nicotine in the atmosphere of air flow; J. Chem. Soc. Jpn. 84 (1963) 71-74.

18. Kobashi, Y.: Studies on pyrolytic degradation of tobacco alkaloids; Jpn. Tob. Salt Public Corp. Cent. Res. Inst. Sci. Pap. 108 (1966) 223-293.

19. Baker, R. R, and K, D. Kilburn: The distribution of gases within the combustion coal of a cigarette; Beitr. Tabakforsch. 7 (1973) 79-87.

20. Baker, R. R.: Combustion and thermal decomposition regions inside a burning cigarette; Combust. Flame (Lond.) 30 (1977) 21-32.

21. Green, C. R.: Some relationships between tobacco leaf and smoke composition; Proc. 173rd Amer. Chem. Soc. (Agric. Food Chem. Div.) Symp. on Recent advances in the chemical composition of tobacco and tobacco smoke, New Orleans, Louisiana, 1977, 426-470.

22. Bokelman, G. H., and William S: Ryan, Jr.: Analyses of Bright and Burley tobacco laminae and stems; Beitr. Tabakforsch. Int. 13 (1985) 29-36.

23. Tso, T. C:, and J. F. Chaplin: Simple correlation and multiple regression among leaf characteristics, smoke components and biological responses of bright tobaccos; U.S. Dept. Agric. Techn. Bull. $1551,1977$.
24. Kramer, C. M., Z. A. Munir and J. V. Volponi: Simultaneous dynamic thermogravimetry and mass spectrometry of the evaporation of alkali metal nitrates and nitrites; J. Therm. Anal. 27 (1983) 401408.

25. Hardy, D. R., and M. E. Hobbs: The use of ${ }^{15} \mathrm{~N}$ and of ${ }^{15} \mathrm{~N}$ and ${ }^{16} \mathrm{O}$ in added nitrates for the study of some generated constituents of normal cigarette smoke; Proc. 173rd Amer. Chem. Soc. (Agric. Food Chem. Div.) Symp. on Recent advances in the chemical composition of tobacco and tobacco smoke, New Orleans, Louisiana, 1977, 489-510.

Authors' address:

Central Research Institute,

Japan Tobacco Inc., 6-2 Umegaoka, Midori-ku, Yokohama, Kanagawa, 227, Japan. 